\title{
TRK-820, a Selective $\kappa$-Opioid Agonist, Produces Potent Antinociception in Cynomolgus Monkeys
}

\author{
Takashi Endoh ${ }^{1, *}$, Atsushi Tajima ${ }^{1}$, Naoki Izumimoto ${ }^{1}$, Tomohiko Suzuki ${ }^{1}$, Akiyoshi Saitoh ${ }^{1}$, Tsutomu Suzuki ${ }^{2}$, \\ Minoru Narita ${ }^{2,4}$, Junzo Kamei ${ }^{3}$, Leon F. Tseng ${ }^{4}$, Hirokazu Mizoguchi ${ }^{4}$ and Hiroshi Nagase ${ }^{1}$ \\ ${ }^{1}$ Pharmaceutical Laboratories, Toray Industries Inc., 1111 Tebiro, Kamakura, Kanagawa 248-8555, Japan \\ ${ }^{2}$ Department of Toxicology and ${ }^{3}$ Department of Pathophysiology and Therapeutics, Faculty of Pharmaceutical Science, Hoshi University, \\ 2-4-41 Ebara, Shinagawa-ku, Tokyo 142-8501, Japan \\ ${ }^{4}$ Department of Anesthesiology, Medical College of Wisconsin, Milwaukee, WI 53226, USA
}

Received June 1, 2000 Accepted December 18, 2000

\begin{abstract}
TRK-820 ((-)-17-cyclopropylmethyl-3,14b-dihydroxy-4,5a-epoxy-6b-[N-methyl-trans-3-(3furyl)acrylamide]morphinan hydrochloride) has been shown to be a potent opioid $\kappa$-receptor agonist with pharmacological properties different from those produced by $\kappa_{1}$-opioid receptor agonists in rodents. To ascertain whether or not these properties of TRK- 820 would be extended to primates, the antinociceptive effect of TRK- 820 was evaluated in cynomolgus monkeys by the hot-water tail-withdrawal procedure. TRK820 given intramuscularly (i.m.) produced a potent antinociceptive effect that was 295- and 495-fold more potent than morphine with the $50^{\circ} \mathrm{C}$ and $55^{\circ} \mathrm{C}$ hot-water tests, respectively, and 40 -fold more potent than $\mathrm{U}-50,488 \mathrm{H}$ and 1,000 -fold more potent than pentazocine in the $50^{\circ} \mathrm{C}$ hot-water test. The duration of antinociceptive effects of TRK- 820 treatment $(0.01$ and $0.03 \mathrm{mg} / \mathrm{kg}$, i.m.) lasted more than $6 \mathrm{~h}$, which was much longer than those of U-50,488H. The antinociception produced by the higher dose $(0.03 \mathrm{mg} / \mathrm{kg}$, i.m. $)$ of TRK- 820 was not inhibited by nor-binaltorphimine $(3.2$ and $10 \mathrm{mg} / \mathrm{kg}$, s.c.) or by naloxone $(0.1 \mathrm{mg} / \mathrm{kg}$, s.c.), although the antinociception induced by a lower dose of TRK- $820(0.01 \mathrm{mg} / \mathrm{kg}, \mathrm{i} . \mathrm{m}$. $)$ was inhibited by nor-binaltorphimine $(10 \mathrm{mg} / \mathrm{kg}$, s.c.). The same doses of nor-binaltorphimine and naloxone effectively inhibited the antinociception induced by the higher doses of U-50,488H $(1.0 \mathrm{mg} / \mathrm{kg}, \mathrm{i} . \mathrm{m}$.) and morphine $(10 \mathrm{mg} / \mathrm{kg}, \mathrm{i} . \mathrm{m}$.), respectively. These results indicate that the antinociception induced by TRK- 820 is less sensitive to nor-binaltorphimine and suggest that it is mediated by the stimulation of a subtype of $\kappa$-opioid receptor different from the $\kappa_{1}$-opioid receptor in cynomolgus monkeys.
\end{abstract}

Keywords: $\kappa$-Opioid agonist, Antinociceptive effect, TRK-820, Cynomolgus monkey, $\kappa$-Opioid receptor subtype

Systematic efforts in searching for compounds which selectively stimulate $\kappa$-opioid receptors resulted in the development of the compound TRK-820, (-)-17-cyclopropylmethyl-3,14b-dihydroxy-4,5a-epoxy-6b-[ $N$-methyl-trans3- (3-furyl)acrylamide]morphinan hydrochloride. It has been demonstrated previously that TRK-820 possesses a highly selective $\kappa$-opioid receptor agonistic activity in bioassays with isolated guinea pig ileum and mouse vas deferens preparations (1). TRK-820 is also a selective and centrally acting $\kappa$-opioid agonist with antinociceptive and sedative activity in rodents (2). This is supported by the finding that

*Corresponding author. Present address for correspondence: Toxicology Laboratory, Pharmaceutical Laboratories, Toray Industries Inc., 3-1-2 Sonoyama, Otsu, Shiga 520-0842, Japan

FAX: +81-77-533-8692, E-mail: takashi_endo@nts.toray.co.jp the antinociception induced by TRK- 820 is selectively inhibited by the pretreatment with the $\kappa$-opioid receptor antagonist nor-binaltorphimine, but not by the $\mu$-opioid receptor antagonist naloxone and $\delta$-opioid receptor antagonist naltrindole. Unlike the other $\kappa$-opioid agonist pentazocine, which blocks $\mu$-opioid receptors, TRK- 820 has little or no $\mu$-opioid receptor antagonistic properties. In behavioral studies, TRK-820 does not produce any significant place aversion or place preference using an unbiased place preference conditioning procedure in mice (3), although other $\kappa$-opioid receptor agonists such as U-50,488H, trans- $( \pm)$ 3,4-dichloro- $N$-methyl- $N$-[2-(1-pyrrolidinyl)-cyclohexyl]benzeneacetamide, and E-2078, a stable dynorphin analog, produced significant place aversion (4). It has been suggested that TRK- 820 produces its pharmacological effects by stimulating subtypes of $\kappa$-opioid receptors different 
from other $\kappa$-opioid receptors.

TRK-820 has been developed as an analgesic for moderate and severe pain and other indications. Clinical studies of behavioral effects of TRK-820 in humans have been performed. Single intramuscular injections of TRK-820 up to $30 \mu \mathrm{g}$ are well tolerated by healthy volunteers, whereas a dose of $40 \mu \mathrm{g}$ TRK-820 produces moderate behavioral/ psychological side effects, but not psychotomimetic activity (Toray Industries, Inc., unpublished data). Thus, TRK-820 was again shown to be different from other $\kappa$-opioid receptor agonists, such as the arylacetamide spiradoline, which cause dysphoria and psychotomimetic reactions $(5,6)$.

In the present study, in order to ascertain whether or not these properties of TRK- 820 would be extended to primates, we investigated the antinociceptive and other behavioral activities of TRK-820 and compared them with those of $\mathrm{U}-50,488 \mathrm{H}$, morphine and pentazocine by using hot-waterinduced tail-withdrawal tests in cynomolgus monkeys.

\section{MATERIALS AND METHODS}

\section{Animals}

Eleven adult male cynomolgus monkeys (Nihon SLC, Sizuoka) weighing between 3.0 and $8.0 \mathrm{~kg}$ were used for the tests. The monkeys were individually housed, fed monkey chow biscuits and given water daily except during testing. They were maintained in a room with a 12-h light / 12-h dark cycle. The monkeys were used repeatedly for the study at the intervals of 6 days or more.

\section{Antinociceptive testing procedure}

A modification of the hot-water-induced tail-withdrawal procedure described by Dykstra and Woods (7) and Dykstra et al. (8) was used. Antinociceptive activity was assessed with hot water $\left(50^{\circ} \mathrm{C}\right.$ and $\left.55^{\circ} \mathrm{C}\right)$ as the nociceptive stimulus. On the test day, monkeys were placed in primate chairs and allowed to adapt to the test environment. The hairs of the lower portion of the tail were shaved. The tailwithdrawal response was induced by immersing monkey's tail (approximately 10 to $15 \mathrm{~cm}$ ) in a thermos of hot water maintained at $50^{\circ} \mathrm{C}$ or $55^{\circ} \mathrm{C}$ (TAITEC, Saitama). The latency for monkeys to remove their tail from hot water was used as the measure of the antinociception. The control tail-withdrawal latencies were measured three times with 20-min intervals. The mean value of the 2 nd and 3 rd measurements was used as the pre-drug control latency. The tail-withdrawal latencies were then measured $0.5,1,2,4$ and $6 \mathrm{~h}$ after drug or vehicle injection. A cut-off time of $20 \mathrm{~s}$ was used to prevent tissue damage. Warm water $\left(40^{\circ} \mathrm{C}\right)$ was used to ensure that the monkeys did not develop a conditioned avoidance response to the hot water stimulus. It was found that all monkeys did not respond to $40^{\circ} \mathrm{C}$ water immersion for more than $20 \mathrm{~s}$.
Antagonistic actions of nor-binaltorphimine and naloxone

In experiments evaluating the antagonistic effects of norbinaltorphimine and naloxone on the TRK-820-, U-50,488Hand morphine-induced analgesia, $50^{\circ} \mathrm{C}$ water was used as the nociceptive stimulus. Only the monkeys that had received TRK-820 alone, U-50,488H alone or morphine alone in the antinociceptive experiments using $50^{\circ} \mathrm{C}$ water were used in this experiment on antagonism. Pre-drug latency values were determined in the same manner as the antinociceptive testing procedure above. In case of norbinaltorphimine antagonism, 3.2 or $10 \mathrm{mg} / \mathrm{kg}$ of nor-binaltorphimine was administered subcutaneously (s.c.), and then the antinociceptive effects produced by TRK-820, $\mathrm{U}-50,488 \mathrm{H}$ or morphine were measured every 7 days for 3 weeks after nor-binaltorphimine as reported (9). In the case of naloxone antagonism, TRK-820 or morphine was administered intramuscularly (i.m.) after determination of the pre-drug latency values. Forty-five minutes after administration of TRK-820 or morphine, naloxone at a dose of 0.1 or $1 \mathrm{mg} / \mathrm{kg}$ was administered by s.c. injection. The antagonism by naloxone against the antinociceptive activities was evaluated at $0.5,1,2,4$ and $6 \mathrm{~h}$ post-TRK-820 or -morphine (Note: The $30 \mathrm{~min}$ value represents analgesic effects of TRK-820 alone or morphine alone).

\section{Data analyses}

Individual tail-withdrawal latencies were converted to \% analgesia according to the following formula: $\%$ analgesia $=\left(T_{1}-T_{0}\right) /\left(T_{2}-T_{0}\right) \times 100$, where $T_{0}$ is pre-latency, $T_{1}$ is the latency after dosing, and $\mathrm{T}_{2}$ is cut-off latency $(20 \mathrm{~s})$. All data represent the mean $\%$ analgesia \pm S.E.M. The dose that produced $50 \%$ analgesia was taken as the $\mathrm{ED}_{50}$ values for each agonist, as calculated from the log-dose vs $\%$ analgesia data using linear regression techniques (10). In the case of nor-binaltorphimine antagonism, the area under the curve $\left(\mathrm{AUC}_{0-6 \mathrm{~h}}\right)$ of $\%$ analgesia vs time $(0-6 \mathrm{~h})$ was calculated. Statistical significance was determined by analysis of variance followed by the Dunnett's test with JMP software (SAS Institute, Cary, NY, USA); $P<0.05$ was considered significant.

\section{Drugs}

The following drugs were used in this study: TRK-820 (Lot No. TN-101), morphine hydrochloride (Takeda, Osaka); $\mathrm{U}-50,488 \mathrm{H}$ hydrochloride, a $\kappa$-opioid receptor agonist (11) (synthesized at the Toray Research Center, Inc., Kamakura); pentazocine hydrochloride (Sankyo, Tokyo); sodium pentobarbital (Tokyo Chemical Industory, Tokyo); nor-binaltorphimine (12) and naloxone hydrochloride (RBI, Natick, MA, USA). All compounds were dissolved in saline (Otsuka, Tokushima). Saline was used as the vehicle control. All test agents except antagonists were administered by intramuscular injections, and nor-binaltorphimine and naloxone were 
subcutaneously administered. The volume of injections was $0.2 \mathrm{ml} / \mathrm{kg}$ body weight for all agents, except for pentazocine that was administered in a volume of $0.1 \mathrm{ml} / \mathrm{kg}$ (the dose of $3 \mathrm{mg} / \mathrm{kg}$ ) and $0.33 \mathrm{ml} / \mathrm{kg}$ (the dose of $10 \mathrm{mg} / \mathrm{kg}$ ). The antinociceptive test agents and doses were randomly assigned.

\section{RESULTS}

\section{General behavior observation}

TRK-820 at doses of $0.003,0.01$ and $0.03 \mathrm{mg} / \mathrm{kg}$, given i.m. (4 animals per group), produced dose-related muscular weakness and sedation such as drowsiness, ptosis and lack of responsiveness to weak external stimuli (e.g., the sound of hand clapping or blowing the breath over the face of cynomolgus monkeys). TRK-820 as well as U-50,488H produced muscular weakness but not muscular relaxation, and intense stimuli such as pinching the skin of the limbs easily brought recovery of the muscular tension. These sedative behaviors lasted for $6 \mathrm{~h}$ in the group of monkeys that received $0.03 \mathrm{mg} / \mathrm{kg}$ of TRK-820. A lower dose of TRK-820 $(0.001 \mathrm{mg} / \mathrm{kg})$ produced little or no sedative behaviors. Similarly, U-50,488H at doses $0.1,0.3$ and $1 \mathrm{mg} / \mathrm{kg}$, given i.m., produced dose-related sedative behaviors. However, the duration of the sedative behaviors produced by U-50,488H was shorter than that of TRK- 820 . The sedative effects reached its peak at $0.5 \mathrm{~h}$, rapidly declined and returned to the pre-injection control level in $2 \mathrm{~h}$ in all 4 monkeys studied. Morphine at 3 and $10 \mathrm{mg} / \mathrm{kg}$, given i.m., produced dose-related respiratory depression, drowsiness, ptosis, mydrisis and lack of responsiveness to the external stimuli in all 4 monkeys given $3 \mathrm{mg} / \mathrm{kg}$ and in all 5 monkeys given $10 \mathrm{mg} / \mathrm{kg}$ of morphine. Furthermore, $10 \mathrm{mg} / \mathrm{kg}$ of morphine produced itching behavior (face scratching) in 2 out of 5 monkeys. These sedative behaviors, respiratory depression and mydriasis lasted for $6 \mathrm{~h}$ in the group of monkeys injected with higher doses of morphine (10 mg/kg, i.m.). Pentazocine at a dose of $3 \mathrm{mg} / \mathrm{kg}$, given i.m. produced sedative behaviors such as drowsiness, ptosis and lack of responsiveness to the external stimuli and these sedative behaviors dissipated in $2 \mathrm{~h}$.

Inhibition of the tail-withdrawal response by TRK-820, morphine, U-50,488H and pentazocine

All monkeys tested withdrew their tails from the $50^{\circ} \mathrm{C}$ and $55^{\circ} \mathrm{C}$ hot water in $2.47 \pm 0.30 \mathrm{~s}$ (mean \pm S.E.M., $\mathrm{n}=11)$ and $1.83 \pm 0.31 \mathrm{~s}($ mean \pm S.E.M., $\mathrm{n}=11)$, respectively, before the drug injection. TRK-820, morphine and $\mathrm{U}-50,488 \mathrm{H}$ given i.m. inhibited dose-dependently tailwithdrawal responses to $50^{\circ} \mathrm{C}$ hot-water stimulus (Fig. 1: $\mathrm{A}-\mathrm{C}$ ). On the other hand, pentazocine at $3 \mathrm{mg} / \mathrm{kg}$ produced a slight antinociceptive effect (Fig. 1D). Ten milligram of pentazocine produced tonic-chronic convulsion in all 3 animals tested and thus the antinociceptive test could not be performed. The antinociceptive effects of TRK-820 and morphine persisted for more than $6 \mathrm{~h}$, whereas the antinociception induced by $\mathrm{U}-50,488 \mathrm{H}$ rapidly declined and returned to the pre-injection level in $4 \mathrm{~h}$. TRK-820 was found to be 295 - and 40 -fold more potent than morphine and $\mathrm{U}-50,488 \mathrm{H}$, respectively, in the $50^{\circ} \mathrm{C}$ hot-water test (Table 1). Similarly, TRK-820 inhibited dose-dependently the tail-withdrawal responses to $55^{\circ} \mathrm{C}$ hot-water stimulus. TRK- 820 was found to be 420 -fold more potent than morphine in inhibiting the responses to the $55^{\circ} \mathrm{C}$ hot-water stimulus (Table 1). However, the antinociceptive potencies of both TRK- 820 and morphine were less in the $55^{\circ} \mathrm{C}$ hotwater test than in the $50^{\circ} \mathrm{C}$ hot-water test (Fig. 2 and Table 1).

\section{Effects of pentobarbital on behavioral and antinociceptive responses}

TRK-820, morphine or U-50,488H produced antinociception at doses that also produced sedative behaviors. To determine if this antinociceptive effect produced by TRK820 , morphine or $\mathrm{U}-50,488 \mathrm{H}$ was due to the sedative effects of the compound that might interfere with the tailwithdrawal responses, the effect of typical central depressant pentobarbital on the tail-withdrawal responses to $50^{\circ} \mathrm{C}$ and $55^{\circ} \mathrm{C}$ hot-water stimuli was evaluated. Pentobarbital at $10 \mathrm{mg} / \mathrm{kg}$, given i.m., produced sedative behaviors such as sleeping and/or drowsiness, yet produced little or no antinociceptive effects with $50^{\circ} \mathrm{C}$ and $55^{\circ} \mathrm{C}$ hot-water stimuli. Pentobarbital at a higher dose of $30 \mathrm{mg} / \mathrm{kg}$ produced a state of anesthesia, yet produced only a slight antinociceptive effect (approximately 20\% analgesia) (Fig. 3).

Effects of nor-binaltorphimine and naloxone on the tailwithdrawal inhibition induced by TRK-820, U-50,488H or morphine

Nor-binaltorphimine at doses of 3.2 and $10 \mathrm{mg} / \mathrm{kg}$ given s.c alone did not affect the tail-withdrawal latencies (data not shown). The pretreatment with the same doses of norbinaltorphimine did not block the inhibition of the tailwithdrawal response induced by higher doses of TRK-820 $(0.03 \mathrm{mg} / \mathrm{kg}, \mathrm{i} . \mathrm{m}$.) or morphine $(10 \mathrm{mg} / \mathrm{kg}, \mathrm{i} . \mathrm{m}$.$) , but dose-$ dependently blocked the tail-withdrawal inhibition induced by a higher dose of U-50,488H (1 mg/kg, i.m.) (Fig. 4: A C). A lower dose of TRK-820 (0.01 mg/kg, i.m.) produced tail-withdrawal inhibition in 2 of 4 monkeys studied, and the tail-withdrawal inhibition by TRK-820 $(0.01 \mathrm{mg} / \mathrm{kg}$, i.m.) in these two monkeys was blocked by nor-binaltorphimine (10 mg/kg, s.c.) (Fig. 4D). Naloxone, at the dose of $0.1 \mathrm{mg} / \mathrm{kg}$, which has been reported to selectively antagonize the $\mu$-opioid receptor $(11,13)$, completely reversed the antinociceptive effect of morphine and had no effect on the tail-withdrawal inhibition induced by TRK- 820 


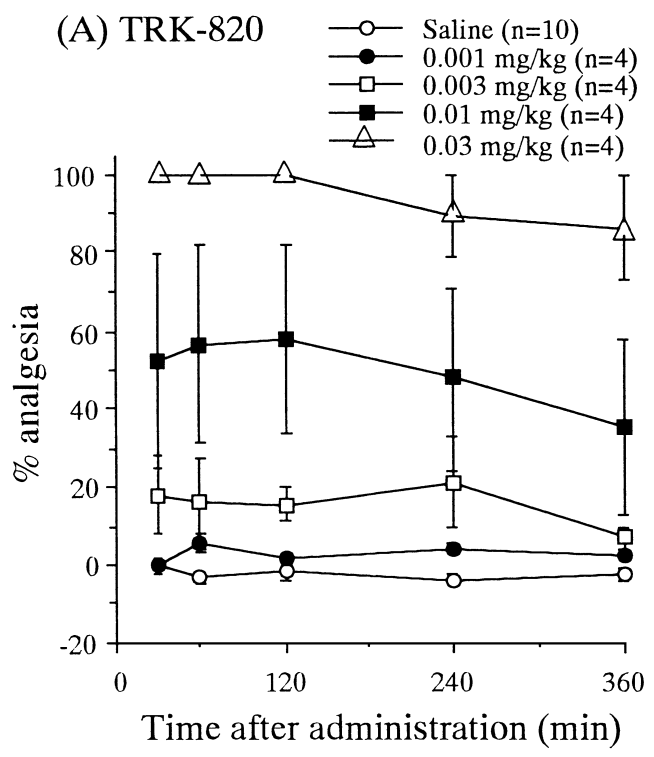

(C) $\mathrm{U}-50,488 \mathrm{H}$

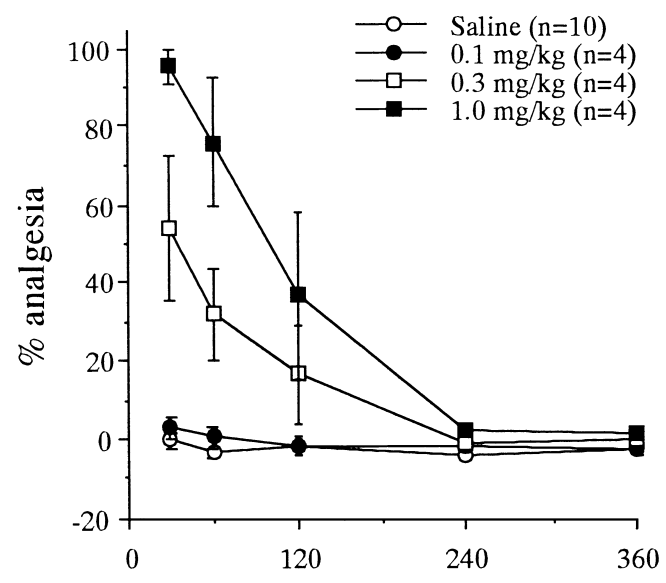

Time after administration (min)

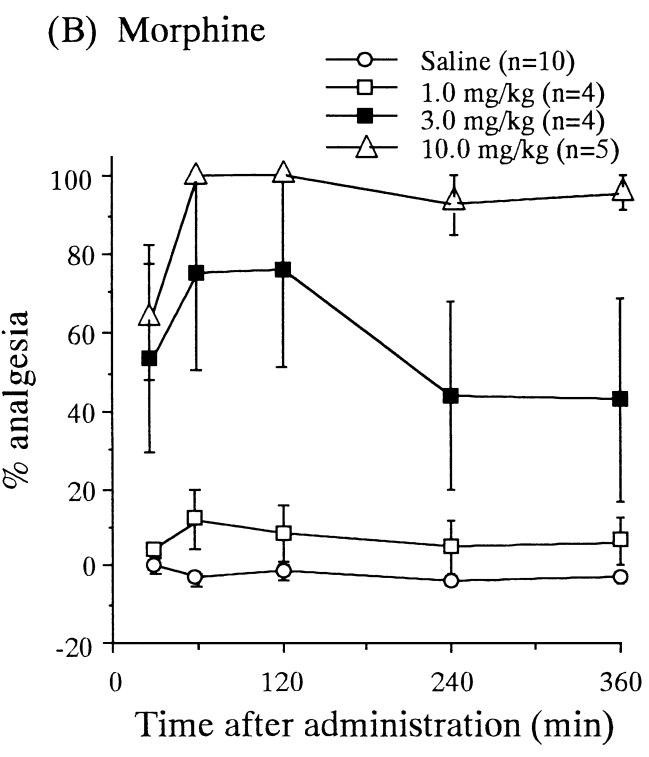

(D) Pentazocine

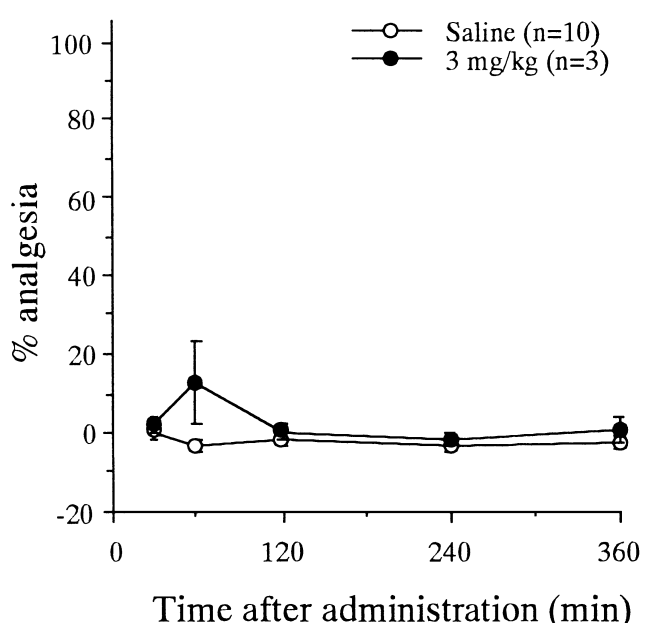

Fig. 1. The antinociceptive effects of intramuscular administration of TRK-820 (A), morphine (B), U-50,488H (C) and pentazocine (D) in the hot water $\left(50^{\circ} \mathrm{C}\right)$-induced tail-withdrawal test in monkeys. The monkeys were intramuscularly given opioid receptor agonists and tail-withdrawal latencies were measured $0.5,1,2,4$ and $6 \mathrm{~h}$ after the treatment. Each value represents the mean \pm S.E.M. The numbers of animals are shown in parentheses.

Table 1. The antinociceptive effects of intramuscular administration of TRK-820, morphine, U-50,488H and pentazocine in the warm water-induced tail-withdrawal test in monkeys

\begin{tabular}{|c|c|c|c|c|}
\hline \multirow[b]{2}{*}{ Drugs } & \multicolumn{2}{|c|}{$50^{\circ} \mathrm{C}$ warm water } & \multicolumn{2}{|c|}{$55^{\circ} \mathrm{C}$ warm water } \\
\hline & $\mathrm{ED}_{50}(\mathrm{mg} / \mathrm{kg}$, i.m. $)$ & Duration (h) & $\mathrm{ED}_{50}(\mathrm{mg} / \mathrm{kg}$, i.m. $)$ & Duration $(\mathrm{h})$ \\
\hline TRK- $820^{\mathrm{a}}$ & $\begin{array}{c}0.0078 \\
(0.0048-0.013)\end{array}$ & $>6$ & $\begin{array}{c}0.012 \\
(0.0069-0.022)\end{array}$ & $>6$ \\
\hline Morphine $^{\mathrm{a}}$ & $\begin{array}{c}2.3 \\
(1.4-3.8)\end{array}$ & $>6$ & $\begin{array}{c}5.9 \\
(3.5-9.7)\end{array}$ & $>6$ \\
\hline $\mathrm{U}-50,488 \mathrm{H}^{\mathrm{b}}$ & $\begin{array}{c}0.31 \\
(0.22-0.43)\end{array}$ & 4 & n.t. & n.t. \\
\hline Pentazocine & $>10$ & n.d. & n.t. & n.t. \\
\hline
\end{tabular}

The $\mathrm{ED}_{50}$ values of antinociception were calculated from the data obtained at ${ }^{\mathrm{a}} 120 \mathrm{~min}$ or ${ }^{\mathrm{b}} 30 \mathrm{~min}$ after the treatment. Each value represents the $\mathrm{ED}_{50}$ with $95 \%$ confidence limits (shown in parentheses). n.d.: not determined, n.t.: not tested. 

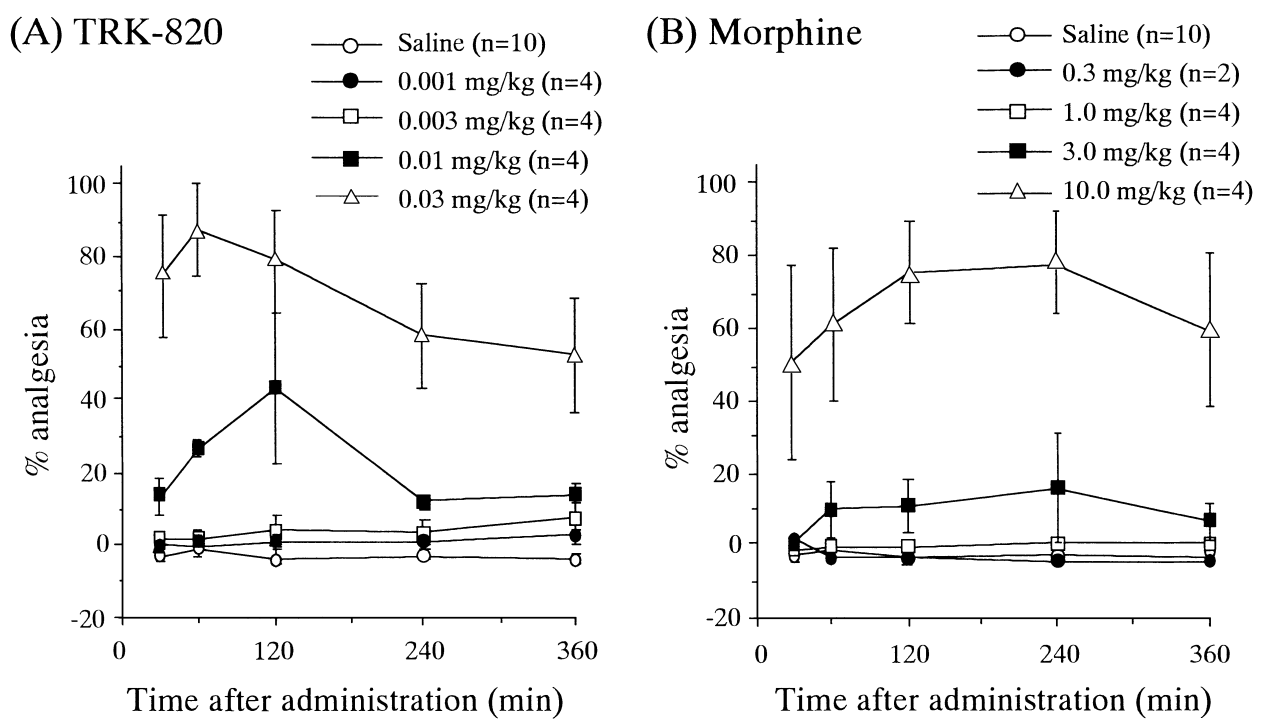

Fig. 2. The antinociceptive effects of intramuscular administration of TRK- 820 (A) and morphine (B) in the hot water $\left(55^{\circ} \mathrm{C}\right)-$ induced tail-withdrawal test in monkey. The monkeys were given intramuscularly opioid receptor agonists, and tail-withdrawal latencies were measured 0.5, 1, 2, 4 and $6 \mathrm{~h}$ after the treatment. Each value represents the mean \pm S.E.M. The numbers of animals are shown in parentheses.

(A) $50^{\circ} \mathrm{C}$

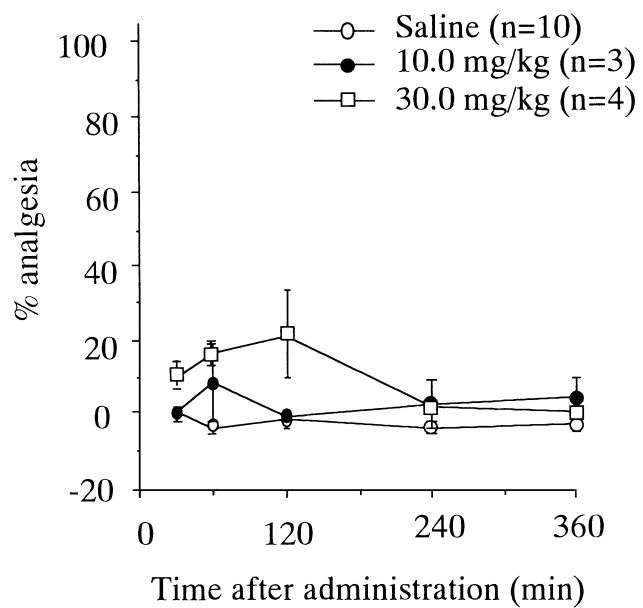

(B) $55^{\circ} \mathrm{C}$

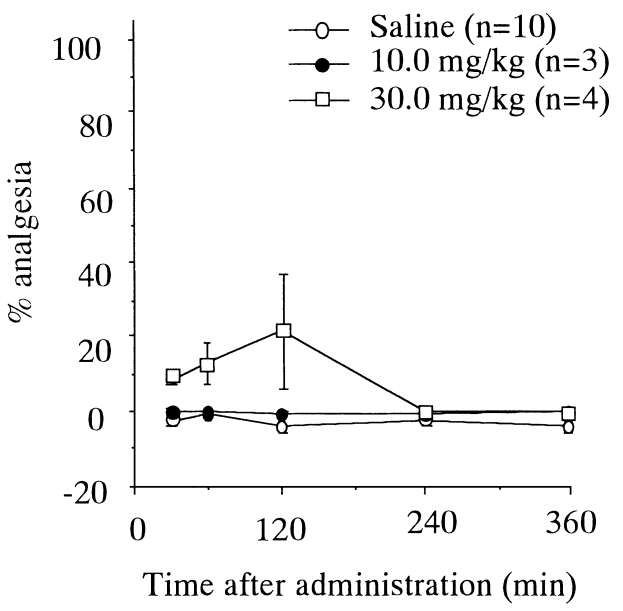

Fig. 3. The effects of intramuscular administration of pentobarbital in the hot water $\left(50^{\circ} \mathrm{C}(\mathrm{A})\right.$ and $\left.55^{\circ} \mathrm{C}(\mathrm{B})\right)$-induced tail-withdrawal test in monkey. The monkeys were intramuscularly given pentobarbital, and tail-withdrawal latencies were measured 0.5 , $1,2,4$ and $6 \mathrm{~h}$ after the treatment. Each value represents the mean \pm S.E.M. The number of animals are shown in parentheses.

(0.03 mg/kg, i.m.) (Fig. 5). However, a higher dose (1 mg $/ \mathrm{kg}$ ) of naloxone blocked tail-withdrawal inhibition induced by both TRK-820 (0.03 mg/kg, i.m.) as well as morphine (10 mg/kg, i.m.) (Fig. 5).

Nor-binaltorphimine at the dose of $10 \mathrm{mg} / \mathrm{kg}$, s.c. did not antagonize the muscular weakness and sedation by a higher dose $(0.03 \mathrm{mg} / \mathrm{kg}$, i.m. $)$ of TRK- 820 , but antagonized these behaviors by a lower dose $(0.01 \mathrm{mg} / \mathrm{kg}$, i.m. $)$ of TRK-820. Concerning U-50,488H and morphine as well as TRK-820, there was a parallelism in antagonism of nor- binaltorphimine between antinociception and muscular weakness/sedation.

\section{DISCUSSION}

We have previously demonstrated in rodents that unlike other $\kappa$-opioid agonists, such as U-50,488H, TRK-820 produces potent antinociceptive effects that are mediated by the stimulation of a type of $\kappa$-opioid receptor other than the $\kappa_{1}$-opioid receptor (14). In this study, we extended our 
(A) $\mathrm{U}-50,488 \mathrm{H}(1.0 \mathrm{mg} / \mathrm{kg})$

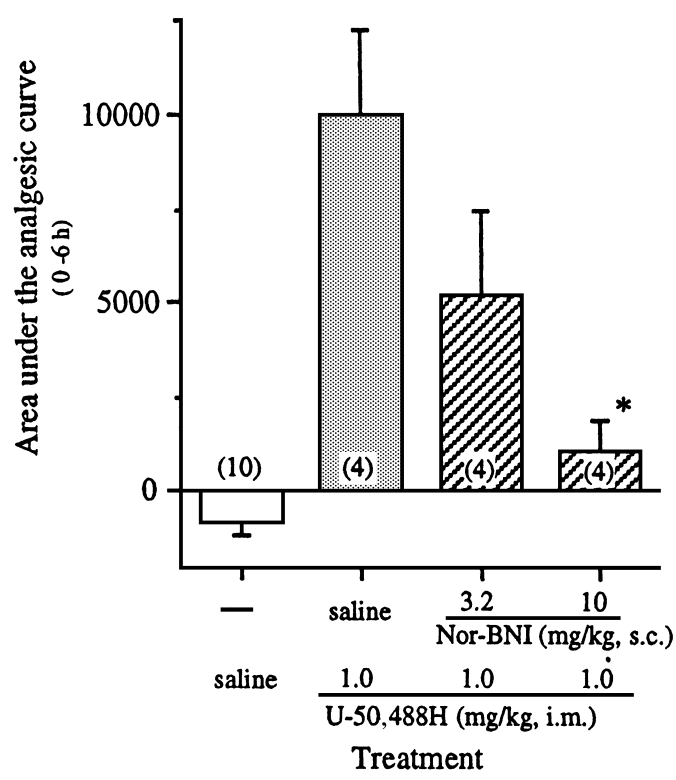

(C) TRK-820 (0.03 mg/kg)

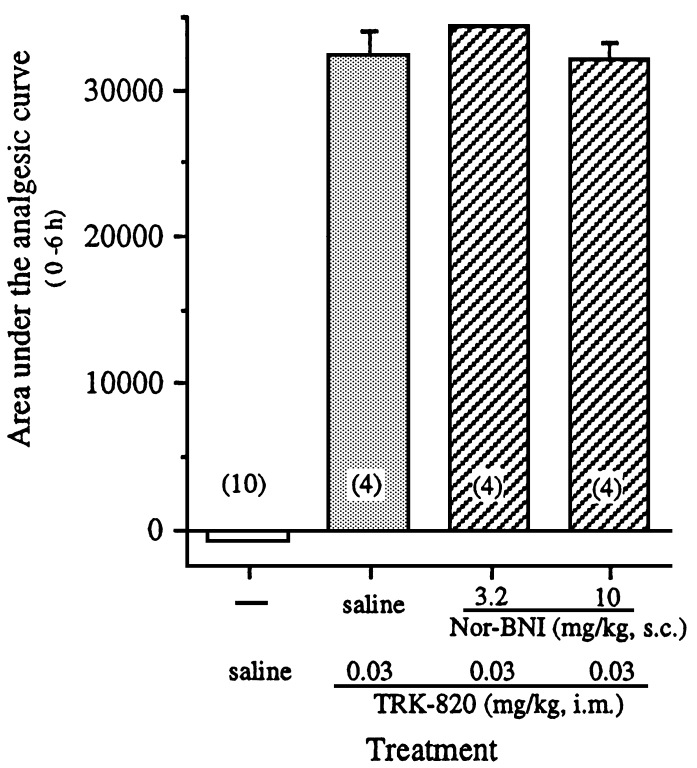

(B) Morphine $(10 \mathrm{mg} / \mathrm{kg})$

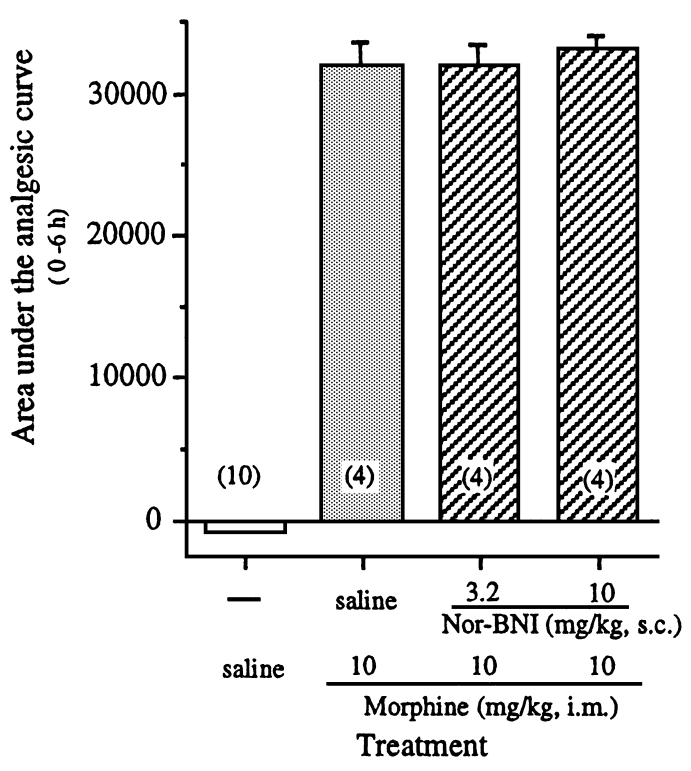

(D) TRK-820 (0.01 mg/kg)

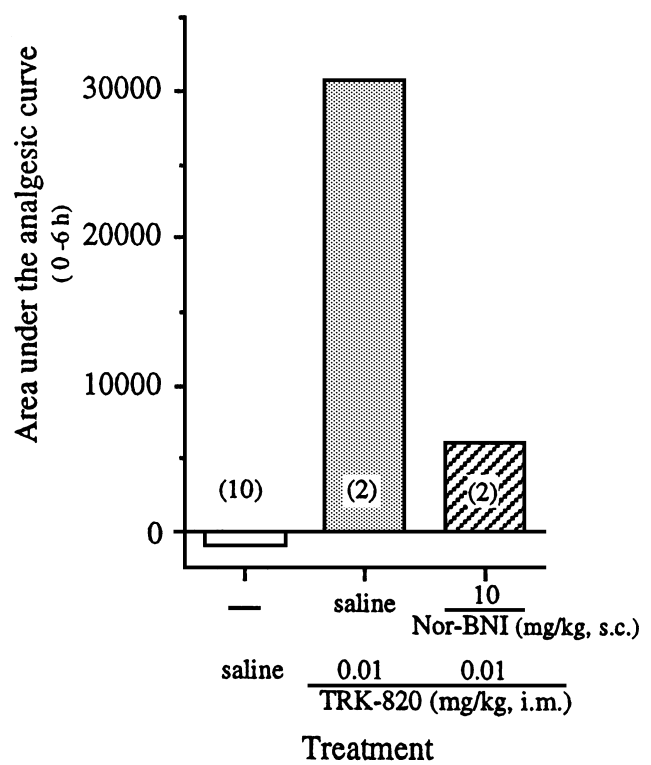

Fig. 4. The effect of nor-binaltorphimine (Nor-BNI) on the antinociceptive effects of intramuscular administration of U$50,488 \mathrm{H}(\mathrm{A})$, morphine $(\mathrm{B})$ and TRK- $820(\mathrm{C}$ and $\mathrm{D})$ in the hot water $\left(50^{\circ} \mathrm{C}\right)$-induced tail-withdrawal test in monkeys. The monkeys were subcutaneously pretreated with nor-binaltorphimine 7,14 or 21 days before the tail-withdrawal test, and tail-withdrawal latencies were measured $0.5,1,2,4$ and $6 \mathrm{~h}$ after the opioid receptor agonists treatment. Each column represents the mean \pm S.E.M. of the area under the curve of $\%$ anlgesia for $6 \mathrm{~h}$. In each column, the number of animals are shown in parentheses. $* P<0.05$, when compared to saline control.

studies to evaluate the antinociceptive properties of TRK820 in the cynomolgus monkeys. We found that TRK- 820 produced potent antinociceptive effects in this animal using $50^{\circ} \mathrm{C}$ and $55^{\circ} \mathrm{C}$ hot-water tail-withdrawal tests. Based on the antinociceptive $\mathrm{ED}_{50}$ values, TRK-820 was 295 - and 495-fold more potent than morphine with $50^{\circ} \mathrm{C}$ and $55^{\circ} \mathrm{C}$ hot-water tail-withdrawal tests, respectively, and 40-fold more potent than $\mathrm{U}-50,488 \mathrm{H}$ and over 1,000 -fold more potent than pentazocine with $50^{\circ} \mathrm{C}$ hot-water tail-withdrawal test. In addition, TRK- 820 as well as morphine produced antinociception with long duration of action. The antinociceptive effects of TRK-820 and morphine persisted for 
(A) TRK-820

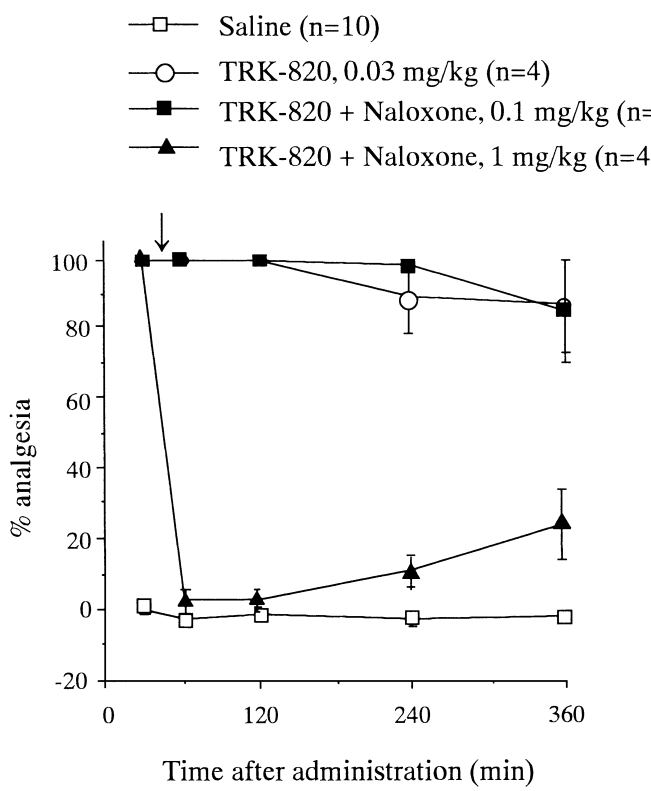

(B) Morphine

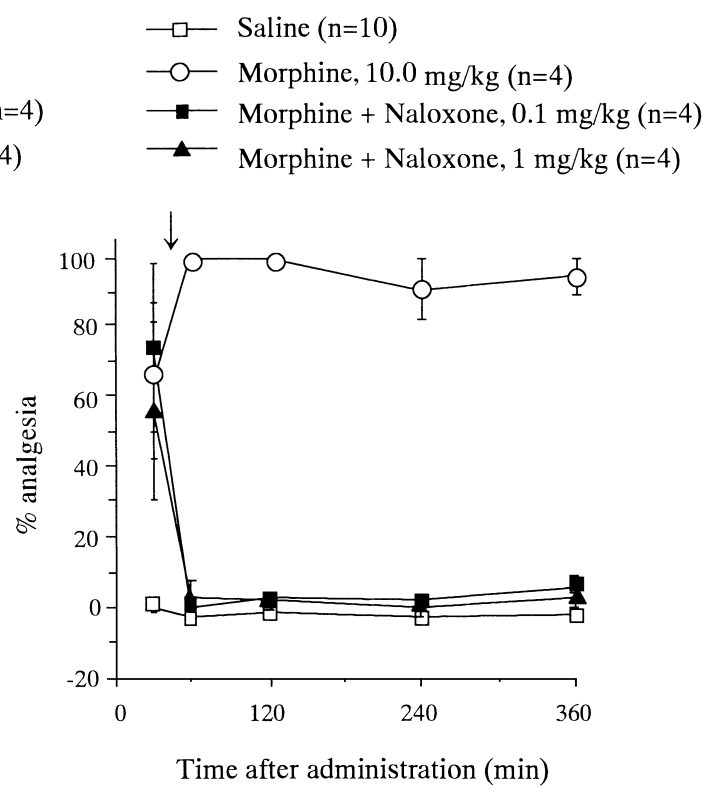

Fig. 5. The effect of naloxone on the antinociceptive effects of intramuscular administration of TRK-820 (A) and morphine (B) in the hot water $\left(50^{\circ} \mathrm{C}\right)$-induced tail-withdrawal test in monkeys. The monkeys were subcutaneously pretreated with naloxone 45 min (arrow) after the intramuscular administration with opioid receptor agonists, and tail-withdrawal latencies were measured $0.5,1,2,4$ and $6 \mathrm{~h}$ after the treatment. Each value represents the mean \pm S.E.M. The number of animals are shown in parentheses.

more than $6 \mathrm{~h}$, whereas the effect of U-50,488H lasted $4 \mathrm{~h}$.

In the mouse abdominal constriction test, the antinociceptive effect of TRK-820 $(0.005-0.04 \mathrm{mg} / \mathrm{kg}$, s.c. $)$ reached its peak at $30 \mathrm{~min}$, rapidly declined and returned to the preinjection level in $2-3 \mathrm{~h}(2)$. In the present study, the duration of antinociception after TRK-820 (0.01 and $0.03 \mathrm{mg} / \mathrm{kg}$, i.m.) as well as morphine $(3.0$ and $10.0 \mathrm{mg}$ $/ \mathrm{kg}$, i.m.) lasted more than $6 \mathrm{~h}$. The kinetics of TRK- $820 \mathrm{in}$ the cynomolgus monkeys and rats after i.m. administration were determined (Y. Hirano et al., unpublished data). The plasma half-lives (about $3 \mathrm{~h}$ ) in the cynomolgus monkeys were longer than those $(0.9 \mathrm{~h})$ in rats when TRK-820 was administered at an i.m. dose of $0.01 \mathrm{mg} / \mathrm{kg}$. Likewise, much longer plasma half-lives $(9.2-16.7 \mathrm{~h})$ were obtained after TRK-820 administered at i.m. doses of $5-25 \mu \mathrm{g} / 60 \mathrm{~kg}$ in a clinical phase 1 study (Y. Hirano et al., unpublished data). Therefore, longer duration of antinociception of TRK-820 in primates as compared with that in rodents may be due to longer plasma half-lives, although we can not exclude the possibility that another factor influenced the duration. Concerning morphine, the plasma half-lives varied between $1.7-3.4 \mathrm{~h}$ in a rhesus monkey given an i.v. dose of 2 $\mathrm{mg} / \mathrm{kg}$, and an active metabolite, morphine-6-glucronide, appeared at the same time (15). In the cynomolgus monkeys, morphine also showed a longer duartion of antinocicption, as compared with that in rodents (that is, the duration of antinociception was $2-3 \mathrm{~h}$ in the mouse abdominal con- striction test), and the longer duration may be due to a longer plasma half-life.

It has been previously reported that nor-binaltorphimine is a long-lasting and selective $\kappa$-opioid antagonist after central or peripheral administration in rodents $(16,17)$. Furthermore, the antagonistic profile of nor-binaltorphimine in rodents is similar to that in primates; that is, nor-binaltorphimine acts as a selective $\kappa$-opioid antagonist with an extremely long duration of action in the hot-water $\left(50^{\circ} \mathrm{C}\right.$ and $55^{\circ} \mathrm{C}$ ) tail-withdrawal assay in rhesus monkeys (9). In the present studies, we demonstrated the same $\kappa$-opioid receptor blocking properties of nor-binaltorphimine in cynomolgus monkeys. Pretreatment (1 to 3 weeks before) with 3.2 and $10 \mathrm{mg} / \mathrm{kg}$ of nor-binaltorphimine inhibited dose-dependently the antinociceptive effects of the higher dose $(1.0 \mathrm{mg} / \mathrm{kg}$, s.c.) of $\kappa$-opioid agonist U-50,488H (Fig. 4).

We have previously reported that TRK-820 has unique profiles for antinociception that are different from those produced by other $\kappa$-opioid receptor agonists such as ICI199441 in arthritic rats (14). While the antinociceptive potency of ICI-199441 is about fivefold less in arthritic rats than in the age-matched normal rats, the antinociceptive potency of TRK-820 in arthritic rats is similar to that in the age-matched normal rats. In the present study, both the higher dose of TRK- $820(0.03 \mathrm{mg} / \mathrm{k}, \mathrm{i} . \mathrm{m}$. $)$ and $\mathrm{U}-50,488 \mathrm{H}$ $(1.0 \mathrm{mg} / \mathrm{kg}$, s.c.) showed maximum antinociceptive responses; that is, the peak responses of the antinociception of 
TRK-820 and U-50,488H were $100 \pm 0 \%$ and $96 \pm 4 \%$, respectively, although the antinociception of U-50,488H was of a markedly shorter duration than that of TRK-820. In the present antagonism study using nor-binaltorphimine, the antinociceptive effects produced by a higher dose of TRK$820(0.03 \mathrm{mg} / \mathrm{kg}$, s.c. $)$ was not inhibited by the pretreatment with nor-binaltorphimine (3.2 and $10 \mathrm{mg} / \mathrm{kg}$, s.c.), although the antinociception induced by a lower dose of TRK-820 (0.01 mg/kg, s.c.) was inhibited by nor-binaltorphimine $(10 \mathrm{mg} / \mathrm{kg}$, s.c.). The same doses (3.2 and $10 \mathrm{mg}$ $/ \mathrm{kg}$, s.c.) of nor-binaltorphimine dose-dependently inhibited the antinociception induced by the higher dose $(1.0 \mathrm{mg}$ $/ \mathrm{kg}$, s.c.) of U-50,488H. However, in the mouse abdominal constriction test, nor-binaltorphimine antagonized the antinociception induced by TRK- 820 and that by $\mathrm{U}-50,488 \mathrm{H}$ to similar extents, and the dose-response curves of TRK- 820 and U-50,488H were shifted to the right by 39 -fold and $15-$ fold, respectively (2). In the rat mechanically induced paw pressure test, nor-binaltorphimine also antagonized the antinociception by TRK-820 and that by ICI-199441, a $\kappa_{1}$ opioid agonist, to similar extents (14). Therefore, the antinociceptive action of TRK-820 was less sensitive to antagonism by nor-binaltorphimine as compared with U-50,488H in the cynomolgus monkeys, unlike in rodents.

Pretreatment with naloxone at a lower dose $(0.1 \mathrm{mg} / \mathrm{kg})$, which selectively blocks $\mu$-opioid receptors $(11,13)$, completely blocked the antinociception induced by the higher dose $(10 \mathrm{mg} / \mathrm{kg})$ of morphine, but not the higher dose $(0.03 \mathrm{mg} / \mathrm{kg}$, s.c.) of TRK-820, indicating that the action of TRK-820 is not mediated by $\mu$-opioid receptors in cynomolgus monkeys. However, naloxone is a non-selective opioid receptor antagonist and blocks $\kappa$ - and other opioid receptors as well as $\mu$-opioid receptors at high doses. We found that naloxone at $1 \mathrm{mg} / \mathrm{kg}$ blocked both TRK-820and morphine-induced antinociceptive effects. When the pharmacological properties of TRK-820 were analyzed using Chinese hamster ovary cells expressing cloned rat $\kappa-, \mu$ - and $\delta$-opioid receptors and human nociceptin receptor, TRK-820 was shown to act as a full agonist for the $\kappa$-opioid receptor, a partial agonist for the $\mu$-opioid receptor, and a low-affinity antagonist for the nociceptin receptor (18). We can not deny the possibility that TRK-820 is relatively resistant to nor-binaltorphimine in cynomolgus monkeys because of partial $\mu$-agonistic action. However, as mentined above, the agonist effects of TRK-820 as well as $\mathrm{U}-50,488 \mathrm{H}$ are sensitive to antagonism by nor-binaltorphimine both in smooth muscle preparations in vitro and in analgesic tests using rodents in vivo $(1,2,14)$. Therefore, in the present experiments using cynomolgus monkeys, TRK820 may selectively act as a agonist on $\kappa$-opioid receptors without $\mu$-agonistic and $\mu$-antagonistic effects, at least within antinociceptive dose range. Taken together, our results suggest that TRK- 820 stimulates $\kappa$-receptors that are different from those stimulated by $\mathrm{U}-50,488 \mathrm{H}$.

TRK-820 as well as U-50,488H produced muscular weakness and sedation but not muscular relaxation, and arousal stimuli such as pinching the skin of the limbs or shaking the limbs easily brought a recovery of the muscular tension. In the present experiments, we used pentobarbital as a negative control drug because pentobarbital also produced muscular weakness and sustained relatively weak muscular tension. Like morphine (19) or U-50,488H (20), TRK-820 produced muscular weakness and sedation at doses that produce antinociception. However, the sedative effects produced by TRK-820 and other opioids were less severe than those produced by the general central depressant pentobarbital. This is supported by the finding that pentobarbital even at high doses did not inhibit the tailwithdrawal responses to hot-water stimuli. Therefore, it is most likely that antinociception measured by the $50^{\circ} \mathrm{C}$ or $55^{\circ} \mathrm{C}$ hot-water tail-withdrawal responses is not due to the influence of the sedative effects of TRK-820 and other opioid agonists, and the inhibition of the tail-withdrawal response is thought to be the antinociceptive action.

In summary, TRK-820 produced potent and long-lasting antinociciceptive effects in cynomolgus monkeys. The antinociceptive effect induced by TRK- 820 may be mediated by the stimulation of a subtype of $\kappa$-opioid receptors different from the $\kappa_{1}$-opioid receptor. TRK- 820 also produced sedative effects, which is distinguished from the antinociceptive effects.

\section{REFERENCES}

1 Nagase H, Hayakawa J, Kawamura K, Kawai K, Takezawa Y, Matsuura H, Tajima C and Endoh T: Discovery of a structually novel opioid $\kappa$-agonist derived from 4,5-epoxymorphinan. Chem Pharm Bull (Tokyo) 46, 366 - 369 (1998)

2 Endoh T, Matsuura H, Tajima A, Izumimoto N, Tajima C, Suzuki T, Saitoh A, Suzuki T, Narita M, Tseng L and Nagase H: Potent antinociceptive effects of TRK-820, a novel $\kappa$-opioid receptor agonist. Life Sci 65, 1685 - 1694 (1999)

3 Tsuji M, Takeda H, Matsumiya T, Nagase H, Narita $M$ and Suzuki T: The novel $\kappa$-opioid agonist TRK- 820 suppresses the rewarding and locomotor-enhancing effects of morphine in mice. Life Sci (in press)

4 Funada M, Suzuki T, Narita M, Misawa M and Nagase H: Blockade of morphine reward through the activation of $\kappa$-opioid receptors in mice. Neuropharmacology 32, 1315 - 1323 (1993)

5 Dionne RA, Dobbins KR and Hargreaves KM: Evaluation of a kappa opioid agonist, spiradoline, in comparison to morphine and placebo in the oral surgery model. Clin Pharmacol Ther 49, 183 (1991)

6 Peters G and Gaylor S: Human central nervous system (CNS) effects of a selective kappa opioid agonist. Clin Pharmacol Ther 45, 130 (1989)

7 Dykstra LA and Woods JH: A tail withdrawal procedure for assessing analgesic activity in rhesus monkeys. J Pharmacol Methods 15, 263 - 269 (1986) 
8 Dykstra LA, Gmerek DE, Winger G and Woods JH: Kappa opioids in rhesus monkeys. I. Diuresis, sedation, analgesia and discriminative stimulus effects. J Pharmacol Exp Ther 242, $413-420$ (1987)

9 Butelman ER, Negus SS, Ai Y, de Costa BR and Woods JH: Kappa opioid antagonist effects of systemically administered nor-binaltorphimine in a thermal antinociception assay in rhesus monkeys. J Pharmacol Exp Ther 267, 1269 - 1276 (1993)

10 Finney DJ: Statistical Methods in Biological Assays, 2nd Ed, Haffner Publishing, New York (1964)

11 Von Voigtlander PF, Lahti RA and Ludens JH: U-50,488: a selective and structurally novel non-mu (kappa) opioid agonist. J Pharmacol Exp Ther 224, 7 - 12 (1983)

12 Portoghese PS, Lipkowski AW and Takemori AE: Binaltorphimine and nor-binaltorphimine, potent and selective kappaopioid receptor antagonists. Life Sci 40, 1287 - 1292 (1987)

13 Ward SJ and Takemori AE: Relative involvement of mu, kappa and delta receptor mechanisms in opiate-mediated antinociception in mice. J Pharmacol Exp Ther 224, 525 - 530 (1983)

14 Endoh T, Tajima A, Suzuki T, Kamei J, Narita M, Tseng L and Nagase H: Characterization of the antinociceptive effects of TRK-820 in the rat. Eur J Pharmacol 387, 133 - 140 (2000)
15 Rane A, Sawe J, Lindberg B, Svensson J-O, Garle M, Erwald R and Jorulf $\mathrm{H}$ : Morphine glucuronidation in the rhesus monkey: a comparative in vivo and in vitro study. $\mathrm{J}$ Pharmacol Exp Ther 229, 571 - 576 (1984)

16 Endoh T, Matsuura H, Tanaka C and Nagase H: Nor-binaltorphimine: A potent and selective $\kappa$-opioid receptor antagonist with long-lasting activity in vivo. Arch Int Pharmacodyn Ther 316, 30 - 42 (1992)

17 Horan P, Taylor J, Yamamura HI and Porreca F: Extremely long-lasting antagonistic actions of nor-binaltorphimine (norBNI) in the mouse tail-flick test. J Pharmacol Exp Ther 260, 1237 - 1243 (1992)

18 Seki T, Awamura S, Kimura C, Ide S, Sakano K, Minami M, Nagase $\mathrm{H}$ and Satoh M: Pharmacological properties of TRK-820 on cloned $\mu$-, $\delta$ - and $\kappa$-opioid receptors and nociceptin receptor. Eur J Pharmacol 376, 159 - 167 (1999)

19 Davis RE, Callahan MJ, Dikerson M and Downs DA: Pharmacologic activity of CI-977, a selective kappa opioid agonist, in rhesus monkeys. J Pharmacol Exp Ther 261, 1044 - 1049 (1992)

20 Tang AH and Collins RJ: Behavioral effects of a novel kappa opioid analgesic, U-50488, in rats and rhesus monkeys. Psychopharmacology (Berl) 85, 309 - 314 (1985) 